\title{
Space, Time and Place in Samuel Beckett's Collected Shorter Plays: That Time, Rockaby, Come and Go, Quad and Cascando
}

Bahman Zarrinjooee ${ }^{1}$, Marzieh Yaghoobi2*

${ }^{1}$ Department of English Language and Literature, Faculty of Postgraduate Department of English Language and Literature, Boroujerd, Islamic Azad University, Boroujerd Branch, Iran,

${ }^{2}$ Department of English Language and Literature, Boroujerd, Islamic Azad University, Boroujerd Branch, Iran

Corresponding Author: Marzieh Yaghoobi, E-mail: m.yaghubi@hotmail.com

\section{ARTICLE INFO}

Article history

Received: December 13, 2017

Accepted: February 10, 2018

Published: April 30, 2018

Volume: 9 Issue: 2

Advance access: March 2018

Conflicts of interest: None

Funding: None

\begin{abstract}
This paper analyzes the concepts of time and space in Samuel Beckett's (1906-1989) Collected Shorter Plays based on Martin Heidegger's (1889-1976) philosophy of being and time. From long time ago, the notions of time and space have an outstanding importance in the life of man, and in every period and time, this subject has its consequences and influential importance on the way people act, behave, think, and confront each other. Regarding philosophy as the study of basic questions of being and knowledge and study of the nature of human thought and the world, these concepts gain especial meaning by means of which a novel and new world of human understanding will be revealed. The reason that the concept of time is important refers to the fact that human being is imprisoned, monitored and controlled through the gates of this concept. They are limited by this philosophical debate, and humanity is nothing and has no meaning out of the concept of time.
\end{abstract}

Key words:

Architectonic,

Dasein,

Being,

Place,

Space,

Time

\section{INTRODUCTION}

When a concept is to be traced in the mentality of human being, a philosopher's task springs up. In every period, the philosophers as those who are studying the principles of existence behavior and knowledge try to conceptualize the notions of time and space in accordance with the conditions and the situations that are specialized to their era; or maybe are deductively in search of eternalizing their thought-provoking interpretations. Accordingly, when one is in search of finding the fundamental interconnection of the mentioned concepts with each other and also their representations in real life or in a literary framework, he/she should be drawn in the vast sea of philosophy and see through the eyes of philosophy to logically comprehend the notions.

Each philosopher has his/her own unique principles through which the reader could reach a concluding state. Thereafter, the reader makes his own interpretation of the philosopher's primary work and the work upon the philosopher's thoughts. The notions of time and space are not far away from this circle. Martin Heidegger as a well-talented German philosopher has his own principles in this path, too. He was extensively perceived as an influential intellectual, philosopher and thinker in the areas of existential phenomenology and philosophical hermeneutics.

The works of Samuel Barclay Beckett (1906-1989) as an Irish avant-garde novelist, dramatist, theatre leader, and poet, deal with an unwelcoming, bittersweet attitude on human nature, often coupled with black comedy and gallows humor. All his short dramatic works are collected in a sort of collection titled Collected Shorter Plays among which the main focus of this paper is to discuss some of them through the lens and the motif of time and being from the perspectives of Heidegger.

Time is an inseparable concept in the life of every single person. Human beings deal with it all through their life, but they also understand that it is really mysterious and weird. People try to measure time through different ways, but this measurement which deals with duration could not be certain because duration is temporary in the life of all human beings. 
In measuring time, man divides the duration into three parts: past, present, and future. However, the question is whether these really exist or not. For Parmenides, the Greek philosopher:

the past and the future are not (now), so they are not real. Further, the present is ad infinitum analyzable into smaller and smaller durations: We can speak of the present day, but part of that day is past (and so nonexistent) and part is future (and so nonexistent). Same for the present hour, the present minute, and so on. Any time you pick out includes times that are not present; there doesn't seem to be an actual, identifiable present time. (Qtd. in Bardon 25)

People do compare the duration of past in relation to present and the period of time with each other. Augustine is an early Christian theologian and philosopher whose writings influenced the development of Western religion and philosophy. He explains that, "nevertheless we do measure time. We cannot measure it if it is not yet in being, or if it has no duration, or if it has no beginning and no end. Therefore we measure neither the future nor the past nor the present nor time that is passing. Yet we do measure time" (ibid).

Consequently, the point is how human being can be aware of time without the existence of past, present, or future. Augustine argues that time only exists in mind. "Memory, sensation, and anticipation leave impressions on us, and it is these that are measured and compared when we make judgments about the passage of time" (qtd. in Bardon 25). Therefore, if the past and future are different, it is because of their divergence in mind. For Augustine time is human being's invention and it does not exist for itself, nor does it show the eternity. Augustine uses this to answer the questions like when there nothing exists but God, why does he create the world at this time not before or later.

\section{HEIDEGGER'S VIEW OF TIME}

Heidegger explained the concept of time from different aspects, which started as follow:

What is in time and is thus determined by time, we call the temporal. When a man dies and is removed from what is here, from beings here and there, we say that his time has come. Time and the temporal mean what is perishable, what passes away in the course of time. Our language says with still greater precision: what passes away with time. For time itself passes away. But by passing away constantly, time remains as time. To remain means: not to disappear, thus, to presence. Thus time is determined by a kind of Being. (Heidegger 2008: 3)

Heidegger explains that Dasein finds itself in the world without wanting it or even knowing the reason of it. Nevertheless, Dasein could create its own life there in the world and be an authentic creature all through its life until its death. As a matter of fact, this brings fear and anxiety to its life. "Anxiety individualizes Dasein for its own most Being-inthe-world, which as something that understands, projects itself essentially upon possibilities" (Heidegger 1992a: 232). Heidegger also declares that, "[f]ear may seem to be essentially future directed, towards some malum futurum, some future evil that might befall me" (ibid149). This fear is the fear for myself, my possessions in this world, my health, etc. which Dasein might and have lost some day. Fear could undo us and make us forget ourselves. In fear "we forget ourselves: think of the saying, he runs around like a chicken with its head cut off" (ibid). But Heidegger thinks that anxiety has a contrary capacity.

Human beings' life will be finished someday. Heidegger believes that in Dasein there is a continual lack of totality, which finds an end with death. Indeed death is the end of Dasein. He also says that "time does not find its meaning in eternity; time finds its meaning in death" (qtd. in Alweiss 117). Heidegger argues that the awareness of one's mortality makes him understand the time. In his lecture The Concept of Time (1924), he asks whether time can find its meaning in eternity. He explains that time cannot find its meaning in eternity, but in death and the existence of finite life. He knows that death is not something, which human beings can control. Heidegger changes the traditional concept of time that says time finds its meaning through eternity. Human beings are mortal and one cannot deny this fact. Therefore, time gets its meaning all through the living part and it cannot be defined by eternity. Heidegger discusses that one cannot get rid of mortality and it is part of one's life.

Heidegger shows that time cannot find its meaning in numbers of clock, but rather it finds its meaning in Dasein and Dasein essence lies in the existence. One comes to understand that human beings are the only creatures who realize the concept of time because they consciously exist in the world and understand its limits in terms of restriction. "The passing of time and indeed such restrictions are thus meaningful only for a being that lives with an understanding of a limit" (ibid 122). Death is something prominent in men's life. "As soon as man comes to life, he is at once old enough to die" (Heidegger 2008: 48). Death is part of one's living and this is why life is temporal. "Death is something that stands before us-something impending" (ibid 294). Death is an entity, which one cannot experience by itself, but one experiences it in others. It is "lifted right out of the possibility of experiencing this transition and of understanding it as something experienced. Surely, this sort of thing is denied to any particular Dasein in relation to itself. But this makes the death of others more impressive" (ibid 281).

Heidegger explains that humans stretch between birth and death, "but death is only the 'end' of Dasein; and, taken formally, it is just one of the ends by which Dasein's totality is closed round. The other 'end', however, is the 'beginning', the 'birth.' Only that entity which is 'between' birth and death presents the whole which we have been seeking" (qtd. in Alweiss 425). People as human beings have responsibility and authenticity in the life long, so the life's temporality and the existence of freedom bring the time into stage. Alweiss states time itself shows that it is we who are responsible for giving meaning to time. This responsibility is indicated through Dasein's finitude.

One of man's problems is that he thinks that time is infinite; whereas he lives in a way that time is finite. However, because of his "knowledge on death [he is] anxious in the face of death. Being-toward-death is essentially belongs 
to human's thrownness" (Heidegger 1992a: 295). Accordingly, this being-in-the world by thrownness and the being-toward-death gives a kind of anxiety. "We must recall that Being-in-the-world is a basic state of Dasein. That in the face of which one has anxiety [...] is Being-in-the world as such" (ibid 230). Anxiety gives the freedom of choosing, giving authenticity in the world. Moreover, this falling bears a kind of threatening entity. Anxiety does not have a threatening entity, but fear does. Anxiety neither does nor encounters the source of threatening, but fear does.

\section{HEIDEGGER'S VIEW OF SPACE}

Space is characterized neither as a subjective nor objective entity, but it contains actions and movements. Not only temporality is crucial for Dasein, but spatiality also plays an important role in it. In Being and Time, being discussion is mainly on its temporality and spatiality, which seems inseparable from being. Being and spatiality "appear inseparably intertwined" (Vallega 58). The meaning of being for Heidegger is as the meaning of existence, or life instead. Human beings occupy the world and each of them is in one point of the earth, as Aristotle says, two people cannot be in the same space at the same time "just like a chess game in which settling the same square meaning removing one of the beads from the game" (Kenner 58-9).

One may regard time and space as crucial concepts of Dasein. Being-in-the-world is an essential characteristic of Dasein. As Heidegger explains:

Being-in is not a 'property' which Dasein sometimes has and sometimes does not have, and without which it could just be just as well as it could be with it. It is not the case that man 'is' and then has, by way of an extra, a relationship-of-Being towards the 'world' - a world with which he provides himself occasionally. Dasein is never 'proximally' an entity which is, so to speak, free from Being-in, but which sometimes has the inclination to take up a 'relationship' towards the world. Taking up relationships towards the world is possible only because Dasein, as Being-in-the-world, is as it is. This state of Being does not arise just because some entity is present-at-hand outside of Dasein and meets up with it. Such an entity can 'meet up with' Dasein only in so far as it can, of its own accord, show itself within a world. (1992b: 84)

In the philosophy of Heidegger, two things that contradict each other and at the same time are much close to each other are being and world. The notion of time is close to the first and the notion of space is close to the second one. Therefore, regarding the issue of space, Heidegger mostly deals with being in the world, living on the earth, under the sky. Thus, human being somehow dwells in the world and being in the world. The word 'in' primordially "signifies a spatial relationship of this kind. It is derived from 'to reside,' 'to habit,' 'to dwell'" (ibid 79-80). Therefore, humans are beings as a vital creature needs to be in the world; being in the space and spatiality is a crucial need of being-in. "Not until we understand Being-in-the-world as an essential structure of Dasein can we have any insight into Dasein's existential spatiality" (ibid 83). Dasein as a being-in-the-world can discover a world at any time and because of Dasein's spatiality in the way of de-severance and directionality, it can encounter with what Dasein is ready-to-hand in its spatiality. "When we let entities within-the-world be encountered in the way which is constitutive for Being-in-the-world, we 'give them space.' This 'giving space', which we also call 'making room' for them, consists in freeing the ready-to-hand for its spatiality" (ibid 146).

The world can be discovered only through its spatiality that gets its meaning with Dasein and other objects' existence in the world. Heidegger talks about the phenomenon of space and considers a room, which contains pieces of equipment inside. The room is conceived as the term of spatiality, but of course, he considers human beings different from other creatures and objects. Dasein is spatial more than any other things in the world because of its being-in entity. "The sign addresses itself to a Being-in-the world which is specifically "spatial"' (ibid 110). Objects placed in the room are in a distinct distance of each other and cannot touch each other, but Dasein can "encounter walls and chairs, can "touch" things. Dasein can really be in the world. Being-in is the formal existential expression for the Being of Dasein, which has Being-in-the world as its essential state" (Butler 95). Human beings are not restricted to a single place like objects and they encounter things. In Heidegger's words: "When we let entities within-the-world be encountered in the way which is constitutive for being-in-the-world, we give them space" (1992a: 146). Humans and space depends on each other. By being-in-the-world, Dasein is put in space and the space can be accessible in the world for Dasein. Spatiality is not "discoverable at all except on the basis of the world. Indeed space is still one of the things that is constitutive for the world, just as Dasein's own spatiality is essential to its basic state of Being in-the-world" (ibid 148).

Heidegger in Being and Time mainly focuses on the temporality and infinity of Dasein, but he also says that, "spatiality is essential to the question of being" (Vallega 9). This temporality and finitude entity encounter Dasein with futurity (being-toward-death). Temporality shows that a person has to leave the world eventually, so this creates a kind of feeling of exile for human beings. Spatiality appears as an "exilic figure in the discourse on temporality" (ibid 9). Exile is forcefully or willingly leaving the home country and when it becomes an outsider, there will be no return. Dasein is going to abandon the world. "Exilic thought figures thought's engagement with its temporal-spatial and finite events. It indicates a thought that thinks in the awareness of its temporality, and therefore that appears as a slipping passage" (ibid 7).

Being-in could be understood as being-in-something. Like food in the plate. By this 'in' the researcher means the relationship of Being which "two entities extended 'in' space have to each other with regard to their location in that space. [...] All entities whose Being 'in' one another can thus be described have the same kind of being as things occurring 'within' the world" (ibid). There is a difference between Objective space and Dasein's spatiality:

On the one hand, "being in something" (sein in etwas) refers to the "space" of things objectively present at hand, as 
well as to the concepts that ground such interpretation (that is, to the "space" of nature, the physical sciences, and the primary philosophical interpretations of spatiality as the "vessel," or container, of entities). On the other hand, Heidegger then goes on to speak of Dasein's In-Sein as "dwelling" a modality of being he will then ultimately ground on "care" (Sorge), the temporal modality that holds together the structure of being-in-the-world. This indicates that spatiality is to be thought in terms other than its traditional interpretations as objective and ideal presence. Spatiality must be rethought in terms of dasein's temporality and finitude. (Ibid 62-3)

One can go back to the world in order to make space becomes conceivable. Space gets its meaning through the environment of the worldhood; therefore, spatiality cannot be perceived in the context of the world. Human beings out of the world are not spatial and being-in-the-world is the crucial factor for Dasein's spatiality. "Indeed space is still one of the things that is constitutive for the world, just as Dasein's own spatiality is essential to its basic state of Being in-the-world" (Heidegger 1992b: 148). Spatiality is part of the question of being and also it plays an important role in appearance of Dasein, and "Dasein through the being in the world comes along with others" (ibid 111).

As much as temporality is important in Dasein, spatiality is important. In addition, for Heidegger spatiality is inseparable concerning the question of being:

The Interpretation of the Being of space has hitherto been a matter of perplexity, not so much because we have been insufficiently acquainted with the content of space itself as a thing [des Sachgehaltes des Raumes selbst], as because the possibilities of Being in general have not been in principle transparent, and an Interpretation of them in terms of ontological concepts has been lacking. If we are to understand the ontological problem of space, it is of decisive importance that the question of Being must be liberated from the narrowness of those concepts of Being which merely chance to be available and which are for the most part rather rough; and the problematic of the Being of space (with regard to that phenomenon itself and various phenomenal spatialities) must be turned in such a direction as to clarify the possibilities of Being in general. (2008: 147-8)

In the above passage being and spatiality entangles with each other. Spatiality is inseparable from the entity of being, but at the same time, it is dangerous for being as well. "Engaging Dasein's spatiality in terms of presence would mean failing to engage the question of being" (Vallega 67). Dasein gets its meaning and entity with being-in-the-word after it there will be nothing as Dasein. Spatiality could occur as a figure of alteration and even leads to the alteration of events and beings. In order to get a better understanding of alterity, it is useful to use temporality that is the central points of Being and Time. "Heidegger's understanding of the moment does not break down time but takes up the three-fold structure of the moment of Dasein in its futurity or being-toward-death" (ibid 86).

Heidegger considers spatiality as a powerful aspect of the question of being. In Being and Time the analyses of Dasein begins with the analyses of spatiality. Heidegger discusses the ontological structure of Dasein as being-in-the-world and then "reinterprets this structure in terms of fundamental temporality" (ibid 60). Question of being in Heidegger's thought is inseparable from the question of language. "For Heidegger the question of being is always at the same time the problem of language" (ibid 69). Expressing words and thoughts is a sign for being in the world. "The way in which discourse gets expressed is language. Language is a totality of words-a totality in which discourse has a 'worldly' Being of its own; and as an entity within-the-world" (Heidegger 1992b: 204). Language belongs to Dasein while he is in the world. Hence, language is connected with being-in-theworld; "language is not to be understood in such an objective, conceptual way, nor is Dasein a subject or entity among other entities in the world. Language has Dasein's kind of being because it arises in the event of Dasein's being-in-theworld, and as the echoing of this disclosedness" (ibid 80).

\section{PHILOSOPHICAL TIME IN PLAY, EMBERS, EH JOE, AND OHIO IMPROMPTU}

Philosophical view of time is concerned with complex and confusing image of time. Samuel Beckett is also the most philosophical writer of twentieth century, although he says, "I am not a philosopher. One can only speak of what is in front of him, and that is simply a mess" (qtd. in Moran 94). His characters are trapped in a world and are hopeless, they somehow are aware of the mortality of their life and the meaninglessness of time in itself. As time earns it's meaning with humans and their mortality, so it brings a kind of anxiety with itself. Anxiety that is the aftermath of the thrownness into the world in some way giving a kind of authenticity for beings in the face of the world that exists through the lifelong from birth to death because death is probable exactly from the time of birth. Being's totality comes to end with death. "Anxiety brings Dasein face to face with its being free for the authenticity of its Being, and for this authenticity as a possibility which it always is" (Heidegger 1992a: 232).

Play is a one-act play, which was written between 1962 and 1963. Three characters appear in identical grey urns with only their heads' appearing. One man (M) in the middle urn, to his right apparently his wife (W1) and to his left his mistress (W2). There is no mask on their faces, but they are not plain and their faces almost become a part of those urns. In the beginning and end, they talk all together, but in the middle, they talk one by one while the other two remain in dark and silence. The man betrays his wife and she smells her off him and threatens to kill herself. Man tries to convince her, but when he understands that there is nothing left to do to convince her, he leaves her and escapes with his mistress. But he finally becomes tired of her and leaves her as well. They talk one by one in an inhuman manner like the one they are programmed to. "Play is a new kind of play for Beckett: a deliberate reduction of stage figures to talking automata who nevertheless retain human emotions and relevance" (Kennedy 92).

In the play, as the temporality of the life of M, W1, and $\mathrm{W} 2$, they have to act in the time of being. They are not in the state of action now; they are somehow trapped in urns and 
just described like a recorded machine. In this play, Beckett shows:

celebrated doctrine that nothing exists except the mind and its ideas. In short there is God's mind and human minds and God puts the ideas of everything directly into one's minds rather than routing it through the medium of an alien matter. To be is to be perceived. Everything that is an idea in the mind. (Moran 97)

Consequently, mind of a self, a being, Dasein is the main creature of the concept of time and living. Heidegger declares, "the primary question is thus not "what is time?... [but] Who is time?"' (qtd. in Alweiss 49). In Play, characters are not living anymore and they know that their time has been finished by death. Their conversations are like a recording tape that is just played by pushing a button:

Yet the immobile and breathless speakers recreate a minimal retrospective plot - of farcical/melodramatic adultery and inevitable suffering - as if enacting the compressed version of a cheap play. And new technical devices in the patterning of audio-visual and verbal effects are used to express, with great precision, a new field of Beckett's vision: aspects of an unromantic life-in-death, recorded as if on tape. (Kennedy 92)

Life-in-death make people aware of what they call time. "In the end, death is just another name for timelessness and, indeed, eternity" (qtd. in Alweiss 124). Time gets it's meaning in human's mind through their life long and loses its meaning with their death. Accordingly, in Play the characters are no longer human beings or no longer can be placed in time. They are just like puppets who repeat what once happened to them:

Play is sombre but not solemn - a fusion of a Dantesque underworld and a tragicomic puppet play. The three speakers are sometimes seen and heard as representative characters recording experiences, expressing suffering; then, at a switch of the light, or while one of them is still speaking, they are perceived to be robot like reciters of 'their' actions and feelings. (Kennedy 97)

W1 at the very beginning thinks that a time will come that all the miseries will end. That time is timelessness that comes with death. The monologue of W1: "till all dark then all well for the time but it will come the time will come the thing is there you'll see it get off me keep off me all dark all still all over wiped out" ( $P$ 95). Andrew Kennedy thinks that Samuel Beckett divides Play into "Chorus, Narration and Meditation - a structural order that illuminates the remembered action and a subsequent vision" ( $P$ 92). The chorus faintly and rapidly repeats, "yes perhaps a shade gone I suppose some might say yes peace one assumed all out all the pain till all dark then all well for the time but it will come" (P 103).

It is so quite that reading the text let the audience connect with the words. They try to come to the point that the end is darkness and dislodging from pain, but again when there is no time. They repeatedly are talking about something to come and waiting for as in life itself in which human beings are always waiting for something to happen like death. They are all waiting for someone to come, for something to hap- pen; they are waiting for some kind of change until ultimately waiting becomes an aim in itself.

They are somehow aware of their death and being in timelessness without any chance to amend. When they die, they are no longer beings. "When Dasein reaches its wholeness in death, it simultaneously loses the Being of its 'there.' By its transition to no-longer-Dasein" (Heidegger 1992a: 281). W2 Expresses that, "as he could testify, if he is still living, and has not forgotten, coming and going on the earth, letting people in, showing people out, were to the effect that she would settle my hash. I confess this did alarm me a little, at the time" ( $P$ 96). Then W2 starts to remind actions and at first addresses W1 as her, but immediately corrects it to that as if being aware that they are not livings anymore. "That meant he had gone back to her. Back to that!" (P 97). In addition, suddenly it reminds them and murmurs that, "All three speakers are transported, unknown to each other, to the hellish time and place they are currently occupying" (Kennedy 94). They meanwhile think about peace to come and nothing remains of pain; M declares, "peace, yes, I suppose, a kind of peace, and all that pain as if [...] never been". After that, there will be no future. "It will come. Must come. There is no future in this" ( $P$ 99). Because there will be no time anymore nothing exists to measure time. Human beings are thrown into the world with the knowledge that life is temporal and their time will end one day:

As a basic state-of-mind of Dasein, it amounts to the disclosedness of the fact that Dasein exists as thrown Being towards its end. Thus the existential conception of "dying" is made clear as thrown Being towards its own most potentiality-for-Being, which is non-relational and not to be outstripped. Precision is gained by distinguishing this from pure disappearance, and also from merely perishing, and finally from the 'Experiencing' of a demise. (Heidegger 1992a: 295)

$M$ thinks life is like a play that humans have thrown in with the knowledge that must end at last. "I know now, all that was just. play. And all this?... When will all this..." In addition, W1 is aware that she could be authentic while she was alive when she says, "I can do nothing... for anybody. any more... thank God. Therefore, it must be something I have to say. How the mind works still" ( $P$ 99). Now in nothingness, timelessness there remains nothing to do. "And that all is falling, all fallen, from the beginning, on empty air. Nothing being asked at all. No one asking me for anything at all" $(P$ 100).

A being exists when being is apprehended, conceived, seen, or taken as a living creature. Existence "depends on being perceived" (Kennedy 96). The past is called a story, "a past that has a story to be conjured up from the shades, from the fragments of memory and language" ( $P$ 93). W1 is the one who talks about the emptiness they stock in and she is the most intellectual character among three speakers; she is still waiting for the pain to be stopped, "Mercy, mercy, tongue still hanging out for mercy. It will come. You haven't seen me. But you will. Then it will come" ( $P$ 98). They stick to the void and nothingness and repeatedly talk about freedom to come. "In Kierkegaard, Heidegger and, Beckett freedom is a vertigo in the face of the abyss of nothingness" 
(Butler 138). Nevertheless, nothing will happen anymore, they are placed in nothingness and timelessness; they are running out of time.

Embers is the radio play, which was written in English in 1957. The opening scene takes place somewhere near the sea. Henry walks next to where he lived all his life and he hears footsteps and knows that those footsteps belong to his father, Bolton. He repeatedly utters some words like stop and down. All through the play, the sea is impersonated as someone who took his father from him and did not even return his body. Henry reminds his father as an old, blind, and idiot person. The sea has an antithetic image for Henry. He remembers the last time he has seen his father alive. When his father asked henry to go with him and he refused, his father ends up with, "washout. That's you are, a washout" (EM 61). It is unknown whether his father willingly go toward death or not, but Henry all through his life punishes himself for not going with him:

Suicide is an ecstatic assertion of absolute freedom; an almost mystical death which allows the suicide to gather time into the living presence of a 'now-point.' At the moment of death, the suicide brings the flow of time to a halt and no longer needs to fear an unknown future and death. (Alweiss 124)

Henry's feeling of guilt is about interpreting his own being because it is not just an arbitrary phenomenon or something that imposes on someone; rather in relation with others being responsible or having debt to the other. Henry feels guilty about his father's death because he has refused to go with him. 'Being-guilty' also has the signification of 'being responsible for' ['schuld sein an']-that is, being the cause or author of something, or even 'being the occasion' for something (Heidegger 1992a: 327). Henry's relation with his daughter is awful because he blames her for the break-up of his marriage. His treatment towards his daughter is like his father's treatment towards him. Henry then calls out for his wife, Ada, and starts speaking with her and wants her to remain with him. Nevertheless, she is dead now and she must return.

All the actions and dialogues take place in Henry's mind. In "Embers, Beckett tried to achieve something less entrancing but more unified, by enclosing the elements of the 'plot' in a deranged man's skull, among numerous other elements" (Kenner 162). Therefore, he prefers not to see the passing of time and sees his father and wife alive with him. Therefore, he is not alone anymore and has someone to talk with. Henry's existence is the repetition of the same element, which ends up in ignorance and disappointment. His father is dead, so he cannot do anything real in this world anymore. His wife seems to be dead as well because, "she speaks when he calls her, and seems more bleakly real than his other thoughts, though her movements, unlike his, make no sound. Is she 'there'? We hear her voice, but only after Henry has called on it" (ibid 164).

Henry is aware that his father is dead, he wants him to come back from dead to be with him and speaks with him, and he understands that he cannot speak with him. Henry just wants him to return and be with him. Henry experiences the death of others and he loses them, but he is not the one who loses the being; he is still alive. "Death does indeed reveal itself as a loss, but a loss such as is experienced by those who remain. In suffering this loss, however, we have no way of access to the loss-of-Being as such which the dying man 'suffers' [...] at most we are always just 'there alongside"" (Heidegger 1992a: 282). All the people that died cannot talk until Henry wants them to and creates their conversation in his mind so when people are not alive anymore and time has finished for them, they have not the power to be in the world and they are not beings anymore to act, talk, think, etc.

It begins with "sea scarcely audible" (EM 59). Maybe the sea as a cause of Henry's father's death is the source to remind that time life is infinite and one should act when he is alive and this is frightening. Through seeing the death of others men conclude that death belongs to a being and every single one of being is going to die. "We are asking about the ontological meaning of the dying of the person who dies, as a possibility of- Being which belongs to his Being" (Heidegger 1992a: 283).

Sea reminds him that he is still alive and the existence of time is for him. "Train it to mark time" (EM 59). He never can forget his father, "there was a great one about an old fellow called Bolton, I never finished it, I never finished any of them, I never finished anything, everything always went on forever" (EM 59). It always continues until his own death forever he himself talks about will be arrived. Death is like being silent because the time has been finished and he cannot do anything anymore. "Dead silence then, not a sound, only the fire, all coal, burning down now." The only thing remains after death is embers and silence. "Silence in the house, not a sound, only the fire, no flames now, embers. Embers" (EM 60)

Henry just wants someone to hear him, to make him feel alive. His father is somewhere unknown and deep. "Are you coming for a dip?" Ada is dead as well because he says, "no matter, no one knows her now" (EM 61). He is repeatedly doing something. "What happened was this, I put them on and then I took them off again and then I put them on again and then I took them off again and then I took them on again and then." Time is just marked by a human being who can think. "Could a horse mark time?" (EM 61). As Butler declares:

Dasein's past is facticity and his future is possibility. Other sorts of entity, stones and animals for instance, have no understanding of the factical situation in which they find themselves and have no possibilities genuinely open before them. As we shall see, this means that they do not have temporality. A stone does not have an authentic past. But this is anticipating later points. Dasein, then, alone "exists." (90)

Henry asks Ada these questions, which show that if you are alive in this world and still have time, you should deal with all humanly affairs. "And I live on the brink of it! Why? Professional obligations? Reasons of health? Family ties? A woman? Some old grave I cannot tear myself away from? Listen to it! What is it like?" (EM 62)

Henry wants to go with Ada toward death, finishes his fighting in life, and puts an end to his life. "Let us get up and 
go" (EM 62). He has some undone jobs in the time of his living which he must fulfill and then puts an end to his time. Henry is waiting for his death:

For time can no longer be understood in view of an end but only in view of something infinitely impending of which we know nothing. However, how can one take death as his point of departure to understand the meaning of time if death remains infinitely impending (of which we know nothing)? (Alweiss 127)

Although men have choices until their death has come, but he cannot have the choice in every dimensions of life. Henry chooses to live instead of dying, but he cannot change his past and just forgets everything that has happened to him. "Man's free choices, of course, are not only limited by facticity cannot choose to be born a Russian if I am born English; they are also limited by themselves. Man can only choose one possibility at a time and this excludes the other possibilities" (Butler 91).

Ada regrets the time when she was alive and had time to do something. "I was never taught, until it was too late. All my life I regretted it" (EM 62). Henry is afraid of touching Ada. On the one hand, he wants to die, but on the other hand, he knows that if he dies, he cannot do anything in timelessness and he chooses to live until he is forced to die. "In our terminology the ending of anything that is alive, is denoted as "perishing"" (Heidegger 1992a: 284). Henry wants something to remind him he is alive and still has time. "Thuds, I want thuds!... Thuds, I want thuds!" Ada does not know about time because she is dead and time does not exist for her anymore when she says: "I have lost count of time" (EM 64). Ada tells to Henry about the time of death when you cannot speak with anyone anymore because after death it is nothing. "The time comes when one cannot speak to you anymore. The time will come when no one will speak to you at all, not even complete strangers. You will be quite alone with your voice; there will be no other voice in the world but yours." Ada should go back to death "then I think I'll be getting back" (EM 65). Death comes with nothingness, void, and timelessness. "Words. Saturday. nothing. Sunday. Sunday... nothing all day... Nothing, all day nothing. All day all night nothing. Not a sound" (EM 66). Time gets its meaning with being and his existence and thoughts, so time is temporal because a being cannot remain eternally and eventually is going to die someday.

Eh Joe was Beckett's first piece, which was written for television in 1965 . The play starts when Joe, a man with grey hairs in his fifties, is in his room and like a child checking under the bed, closing the window, drawing curtain, opening the door, looking out, locking the door and does the same with cupboard. When he sits on the edge of his bed, he thinks that he is safe; but he is not. He hears a woman's voice addressing him; while she goes on, the camera moves closer and closer. Joe listens to her motionless and his eyes remain open without even blinking. The voice utters nine short speeches. The voice begins with expression that he is all alone in this world and no one is there to hear him but himself.

The actions of Joe before the voice shows that he fears in the face of threatening objects. Heidegger says, "in falling,
Dasein turns away from itself. That in the face of which it thus shrinks back must, in any case, be an entity with the character of threatening" (1992a: 230). Fear undone him and makes him not fulfill anything along his lifelong. Fear is a sign of inauthenticity; hence, Joe cannot act as an authentic person and handle his life. "Why don't you put out that light?. There might be a louse watching you. Why don't you go to bed?" (EJ 128). Joe forgets who he is and what is going to happen to him, the voice just wants to remind him of the situation that he is a mortal creature and going to die.

$\mathrm{He}$ is all alone in life and there is no one to hear him and make him know that he is still alive and he has still time to act. He is desperately waiting for his death to come and put an end to his sorrowful life. Heidegger declares, "death is Dasein's own most possibility" (qtd. in Butler 140). Day after day, he becomes weaker and gets closer to death. "Weaker and weaker till not a gasp left there either. Is it that you want?... Well preserved for his age and the silence of the grave. That old paradise you were always harping on... No Joe... Not for the likes of us" (EJ 128). The woman's voice reminds Joe that his time is temporal and he is not going to live forever. The time finally will arrive to force him to leave his safe place and the temporality of life will show itself. In Alweiss's words:

[w]e can never divorce ourselves from our temporal existence: 'eternity as a point of departure is never at our disposal.' The only viewpoint that is at our disposal is the temporal one. Hence, time, indeed even eternity, can only be understood from time. It is from our temporal vantage point alone that we can understand the meaning of time. (120)

The voice declares that I will go soon and you remain in silence and all alone and reminds him how he made the girl commit suicide. Besides, he is going to join them anyway because time is temporal. He just lives and passes his life in a "physical environment except mentally and so invents an endless 'story', which, although obviously drawn from his past, in fact operates existentially" (Butler 92).

Ohio Impromptu is written in 1980. Two old men with black coats and long white hair at the right angles of a table sit in withe chairs. The Listener (L) and Reader (R) who faces down and their faces are hidden. They look like twins. It is a play about a sad tale, which is read by Reader. Reader has a book in front of him that is open at the last pages. As soon as $\mathrm{R}$ starts to read, L knocks on the table and makes $\mathrm{R}$ repeat the last sentence or continue. At last, when L repeatedly knocks on the table, nothing left from the book to be read. L insists on knocking, but nothing more to read. The two men stare at each other as if they were stones until the light fades away.

The sad play that is read by $\mathrm{R}$ begins on Isle Swans; it goes on in a room and remains in a deeper inside. The role of mind is profound here. The place seems unfamiliar to him, but he has to move. "In a last attempt to obtain relief he moved from where they had been so long together to a single room on the far bank" (OI 173). In order to relieve himself and get away from pain and suffering he leaves his place toward unfamiliar one. "Relief he had hoped would flow from unfamiliarity. Unfamiliar room. Unfamiliar scene. Out to where nothing ever shared. Back to where nothing 
ever shared. From this he had once half hoped some measure of relief might flow" (OI 173).

He dreams and in his dreams "he had been warned against this change. Seen the dear face and heard the unspoken words, Stay where we were so long alone together, my shade will comfort you" (OI 174). Remaining in one place is safe, but in order to know the self and life he has to do it:

Questions about one's self, life, past, present, future, why? Where? When? Who? Etc... Will never cease to be mysterious and torturous to one's mind, thus predicting the unknown to come is a distraction by which one lives. However, it would be contradictory to depict the act of waiting in Becketttt in purely stoic way and to ignore the fact that time is being killed in vain whereby the expected will never arrive and the future will never be different from the past or present. (Shalghin 115)

Whatever he has done before alone cannot be undone because past contains the present and future, so what happened just happened. "No. What he had done alone could not be undone. Nothing he had ever done alone could ever be undone. By him alone" (OI 174). Fear does exist in him, which might let him forget who he is. "In this extremity his old terror of night laid hold on him again." A man couple of times appears to him and says, "in this extremity his old terror of night laid hold on him again" (OI 174). Although they never chat, they combine and become one finally. This gives him hope deeply inward. Heidegger once again ties moods to the burden character of Dasein: "Hopelessness, for instance, does not tear Dasein away from its possibilities, but is only one of its own modes of being towards these possibilities" (1992a: 279). The tale is finished while they turned into stone and somehow cease to be and left the world into interior beings:

So the sad tale a last time told they sat on as though turned to stone. Through the single window dawn shed no light. From the street no sound of reawakening. Or was it that buried in who knows what thoughts they paid no heed? To light of day. To sound of reawakening. What thoughts who knows. Thoughts, no, not thoughts. Profounds of mind. Buried in who knows what profounds of mind. Of mindlessness. Whither no light can reach. No sound. So sat on as though turned to stone. The sad tale a last time told. (OI 175)

The mind plays a central role in Ohio Impromptu: "Thoughts, no, not thoughts. Profounds of mind" (Cohn 363). Mind and body work together, so they are temporal and their time will finish someday. "Kant has a solution that purports to bind together body and mind, Reality and consciousness. He observes that Time as consciousness of changing me and that for me to be conscious of change there must be something outside me that is permanent" (Butler 103).

\section{TIME AND SPACE AS KEY NOTIONS IN THAT TIME AND ROCKABY}

One can say that Beckett's writings are a collection of philosophical viewpoints. His works create an atmosphere of existential anxiety, loneliness, and human submission to the merciless course of the world. Beckett's characters portray a confused and alienated humanity without any place and of nowhere; a man who is not comfortable in the world and the one who is lost in a meaningless vain. Every play and the pieces of prose relay and deepen this dark recognition of the human condition, generating a general worldview called 'Beckettian view point.'

Beckettian view calls for a philosophical interpretation. In fact, there are some vague clues embedded in his plays along with the suggestions on purposeful philosophical intent. The significant pessimistic atmosphere, the gloomy post-apocalyptic scenes, loan characters and the dominant sense of the confusion and meaninglessness of life or as Beckett himself states the 'issueless predicament of existence' has made many critics figure out the overall philosophical viewpoints, which Beckett assumed to subscribe.

However, it is difficult and complex to perceive the exact relationship between Beckett and philosophy. Obviously, Beckett is not a philosopher; if he were, he would not have required being involved in art. As a writer, Beckett seriously resisted every trying to impose any philosophical view or meaning on his work. Beckett in fact refuses philosophy and his use of viewpoints is always associated with silence, ambiguity, and humorous counterpoint. Viewpoints are presented somehow as glorious symbol that stay apart from the miserable human condition. Viewpoints console, celebrate, amuse and entertain, but they are always also illusions, exaggerations, blinkers, detours and misillustrating that take the reader merrily beyond the real and passionate circumstances of the world condition.

Time and Being ascertain each other in a one-to-one relation. Here being contains presenting in the world and not just placing like animals, but existence of human beings. Being and time, or time and Being, can be considered as a name for the relation between these issues. It contains both issues and reflects their interdependent relation to Heidegger who focuses on Dasein as being, a search for a self and even more than just a self: "clearly he does not just want to "find himself' in the romantic cliché- he wants to find 'the Self', that is, something that will render 'the mess' intelligible, something really quite like Being, as we shall see" (Butler 88). Time can be distinguished by presence and as soon as presence comes to mind, it is avoidable that past and future do not come to mind. "The making-present which interprets itself-in other words, that which has been interpreted and is addressed in the 'now'-is what we call 'time"' (Heidegger 1992b: 460).

In order to understand time one has to come to Being which Heidegger calls, “'Dasein' - live with such an understanding. For what distinguishes us from other living beings is that our entire existence is informed by the fact that we are mortal" (qtd. in Alweiss 122). In addition, being which is mortal is also set by time, so time is temporal. Men feel time because of mortality, because they know that they are going to die without any exception, which is the reason that they come up with time. "Understood existentially, birth is not and never is something past in the sense of something no longer present-at-hand; and death is just as far from having the kind of Being of something still outstanding, not yet present-at-hand but coming along" (Heidegger 1992a: 426). Heidegger also believes that, "only because we are finite is 
there something called time.... The meaning of time does not lie in eternity which is beyond our grasp. Rather it lies in an end, and that end lies within our grasp" (qtd. in Alweiss 122).

One could get a good and authentic understanding of time only by paying a great attention to his mortality and thus to finitude entity. Mortality means all the humans are condemned to die without exception. Death is something that is probable in anytime through life, but it is also the only thing that cannot be experienced by one and humans can only see it in other people, not themselves. Men never ever could experience their own death; the death of a person is just for others not himself. "We never die; we never live our end" (ibid 127).

That Time is one act play that was written in 1974. Audiences see a man's face with long white hair and regular breathing. He remains silent all through the play. Beckett in a draft has a head on pillow, which is waiting for his death, an unavoidable part of life. Hence, the only thing that is visible on the stage is a face and the only thing that is heard is the three voices that represented him in different points of his life. A speaker reminds the childhood, B is in a relation with a lover, and $\mathrm{C}$ represents the old man seeking for a shelter. The fragmented life story of a man addresses him. "The nameless protagonist, addressed as 'you' 'tu' in Beckett's French translation, is an everyman, and like the medieval Everyman at the point of death, he re-views his life" (Cohn 332). Memories and fiction melt together in order to reconstruct life. The three speakers give different times in his life, but the spectators sit in darkness and they are unaware of time and time has little meaning for them in those moments.

That Time is deeply concerned with human psyche. Beckett goes deep to a radical fear of men, fear of nothingness, timelessness, void, of never could have the memory or sequence of time anymore which comes with death; he creates all those memories to escape the emptiness. Those things you "kept making up to keep the void out just another of those old tales to keep the void from pouring in on top of you the shroud" (TT 138). Therefore, voices go through different points of time in his life in order to scape timelessness from his mind. "The head's memories are heard by him and us through three spaced loudspeakers. When words reach him, his eyes close; they open twice during the course of the play, and, finally, when he smiles. Each loudspeaker delivers its own story" (Cohn 332). In other words, they question mind in memory that seems mysterious for both mind and body in the field of existence.

A starts a vain search for his childhood, but never be successful and remains all alone, $\mathrm{B}$ starts with a girl and exchanges the vows of love, but he as well finishes up with loneliness "no sound not a word only every now and then to vow you loved each other just a murmur one thing could ever bring tears till they dried up altogether that thought when it came up among the others floated up that scene" (TT 138). In addition, $\mathrm{C}$ is alone all the time in his old age who seeks for a shelter from a winter rain. The writer "bent his considerable talents to rendering aspects of memory that might be familiar to anyone. An old man perhaps on his deathbed absorbs memories, for the most part passively, but with an occasional 'no' of self-correction" (Cohn 332). Libera's gives a summary as:

Looking at the play allegorically, we might see it in the following terms: childhood is the period of ignorance when man can naively and almost successfully deceive himself concerning his isolation.; early youth is the period of love, during which one creates the illusion of being in communication with someone else.; old age is the period of faith, in which one treats «ctitious beings as if they were real. (Qtd. in Cohn 333)

He never captures the temporal entity of time which shows that life is finite and human beings are mortal. Each voice repeats fix phrases that show the fragmented of his life story and give a "solution of continuing" (Cohn 333) for recreation of life when the memories and fiction melted with each other. Time in this play is the shade of memories in Dasein's temporal life between birth and death. That Time indicates the finitude of Dasein that shows that there is ending in speech and existing.

Time and life are for a self and there is no time for stone or animal that can never go back in time through their memories. 'Dasein must also be called 'temporal' in the sense of Being "in time"' (Heidegger 1992b: 429). Time is a suitable title in this play. It starts with the two words 'that time', "that time you went back that last time to look was the ruin still there where you hid as a child when was that" (TT 137). Besides, it finishes with "no time" "something like that come and gone come and gone no one come and gone in no time gone in no time" (TT 41). The voices mention memories through the play, but they conclude that the end is nothingness, void, no time and he is going to place in timelessness after death. Therefore, he wants to hide in the memories in order to escape from death. "All gone long ago that time you went back that last time to look was the ruin still there where you hid as a child" (TT 137). He is waiting there and delaying until death comes. "There stood waiting with the night bag till the truth began to dawn" (TT 139).

Rockaby was written in 1980 with just one character. It starts as a woman (W) dressed in a grown and sits in a chair. She speaks barely through the play; she rocks her chair and stops it while a voice (V), a recorded voice of the woman, talks. As she moves, she hears a dull-recorded voice that retells details of her own life. "A little softer each time" $(R C$ 166). The motion of the rockaby and the appearance of $\mathrm{W}$ give a ghostly atmosphere to the play. The woman is prematurely old with untidy grey hair and her grown is described as "black lacy high-necked evening growing. Long sleeves" ( $R C$ 165). Wood is described as pale that is rocked by the woman and a rock that is slight and slow which is controlled by her. Thus, a human being is the one who has a self and time has meaning for it in the limitation of the life long, but not for objects. Rockaby refers to a traditional lullaby in which a cradle falls from a treetop; therefore, brings the image of birth and death together. Birth to death is exposed as a time long of life and the juxtaposition of these two shows the extreme probability of death exactly from the moment of birth so the temporality of time. 
The voice presents her thoughts and more clearly her memory, while she rocks back and forth in rocking chair. $\mathrm{V}$ at first explains, "till in the end the day came in the end came close of a long day" ( $R C$ 166), the end of time, the end of her life, the end of her. Time passes for all creatures like her and at last ends. Whatever they do in their life, they should know that time is finite; they go toward timelessness. "All Dasein's behavior is to be interpreted in terms of its Being-that is, in terms of temporality" (Heidegger 1992b: 456-7). V talks about, "famish eyes to see be seen no a blind up like hers" ( $R C$ 169). Human beings cannot see they are mortal and time is finite. She in her memories remembers her mother whose time ends as well, "dead one day no night dead one night" ( $R C 170)$.

At the end of the final part, the woman fails to join in with the voice; the movement stops, she becomes motionless and her head slowly inclines. "Rock her off stop her eyes fuck life stop her eyes rock her off rock her off” ( $R C$ 171). She died and mixed with her voice and timelessness; she continually says, "Time she stopped" ( $R C 166)$, each stopping of rockaby is a probability for being the last stop. Time is going to stop for her eventually. Each rock shows all her effort in the world through her life, which finally ends in motionless, and death.

\section{BEING AND ARCHITECTONIC IN COME AND $G O, Q U A D$ AND CASCANDO}

The readers are always in dialogue, not only with other people, but also with everything in the world. Everything addresses human beings in a certain sense. Each man is uniquely addressed in his particular place in the world. One can see one's exterior only through others' perspectives. In Toward a Philosophy of the Act Bakhtin introduces an "architectonic" or schematic model of the human psyche, which consists of three components: "I-for-myself," "I-for-the-other," and "other-for-me." Other-for-me describes the way in which others incorporate my perceptions of them into their own identities; this is obvious in Come and Go when friends talk about the absent friend. One asks question and other answers and gives idea about the absent one: "FLO what do you think of Vi?/Ru see little change" (CG 123).

Three women in the play are in consistent dialogue with each other. Two of them talk about the third when she is absent. Every woman takes turn to disappear in the darkness nearby, giving a chance to the other two to gossip about her. Gossip here is not a negative quality. On the contrary, Beryl Fletcher and John Fletcher note, "none of them [the three ladies in Come and Go] is concerned with her own troubles, only with thoughts and memories of each other, sitting with clasped hands "as in the old days" ( $C G 126)$.

Friends' interaction with each other is considered as what Heidegger calls "being-with." The women do not talk much. They whisper in one another's ears get startled and exclaim “Oh!” (CG 20). They express their sadness about other life tragedy. In life, sisters, even twins, are different in personalities. In his stage direction, Beckett writes that the three "ohs" mentioned by the three women that are "three very different sounds" (CG 22). This part of play shows three friends' in- teraction and responses to each other that is a way towards their individualism.

Referring to Heidegger's philosophy one can say that the world is full of people and they experience it together. At the end of the play, three sisters feel happy in joining each other. They are happy to stay together, enjoying one another's company. This is clear from the gesture at the end of the play:

they join hands as follows: VI's right hand with RU's right hand, VI's left hand with FLO's left hand, FLO's right hand with RU's left hand, VI's arms being above RU's left arm and FLO's right arm. The Three pairs of clasped hands rest on the three laps. Silence. ( $Q U 125)$

Quad is another play, which contains the notion of space and place. A television play was written in 1981. It has four characters who silently walk and remain silent. They never touch and avoid the center. It is based on regular movements. The four are like mime players. Players, "each following his particular course" (QU 176). They complete the courses without any words or touching each other. Some continue and some exit then again and again. They follow patterns:

1st series: 1, 13, 134, 1342, 342, 42

2nd series: $2,21,214,2143,143,43$

3rd series: $3,32,321,3214,214,14$

4, 43, 432, 4321, 321, 21 (QU 176)

Apart from the color, which is distinctive by each other, the manners of their paces are varied as well. "Each player has his particular light, to be turned on when he enters, kept on while he paces, turned off when he exits" ( $Q U$ 177). The second part of the play begins and is called as Quad II. In Quad II, "no color, all four in identical white gowns, no percussion, footsteps only sound, slow tempo, series 1 only" ( $Q U$ 179). Beckett traces a place, which is the same after thousand years while the mute walkers still are in their performances. In the play, nothing is uttered, so there exists nothing as communication with other beings. "In this more general kind of communication, the Articulation of Being with one another understandingly is constituted" (Heidegger 1992a: 205). Communication is a kind of being with each other and being in the world and feeling the spatiality. However, in Quad there is nothing as Dasein's spatiality. They act as movable objects that never talk and never touch. They just move like a programmed machine in specific patterns. There are regular sounds, movements, footsteps like those that they just act in a given manner. "Percussion intermittent in all combinations to allow footsteps alone to be heard at intervals" ( $Q U 177)$.

The characters seemed they are obliged ones who trap in an unknown place and like they are cursed in a monotonousness. "Anyone who has seen this work can attest to its hellish monotony" (Weiss 123). They are imprisoned somewhere and repeatedly do the same movements. "In Quad 1 and Quad 2 there is a sense of being obligated and thus trapped by the technology recording the protagonists on screen" (ibid 125). They are forced to repeat actions continuously "they are trapped in a quad and, in their very movements, forced to repeat the same motions" (ibid 126). Even after thousands of years, which show that they exist in timelessness, they still do the same. "In fact, Beckett said to Müller-Freienfels that the time that has lapsed between Quad 1 and Quad 2 is ten thousand years" (ibid). 
Talking and expressing words with each other shows that a being is in the world in connection with other beings. Heidegger says:

Being-with belongs to Being in- the-world, which in every case maintains itself in some definite way of concernful Being-with-one-another. Such Being-with-one-another is discursive as assenting or refusing, as demanding or warning, as pronouncing, consulting, or interceding, as 'making assertions', and as talking in the way of 'giving a talk.' (2008: 204)

They do not talk or communicate, so they are just like objects. "Counter-experience offers the experience of what irreducibly contradicts the conditions for the experience of objects" (Wynands 114). Therefore, Quad does not contain Dasein who has not spatiality, which is a crucial feature of a person because they are not beings in the world. Temporality and spatiality show that Dasein is going toward death. "Heidegger's focus is never on the fact of death, but on $D a$ sein's living awareness of its finitude as the ground of meaning" (Ruch 72). Being toward death somehow gives meaning to their life, but in Quad the readers see that even after years there is no death because they are not beings anymore.

Cascando is a radio play, which was written in 1961. The play begins while there is a search to put an end to language and story. "Story ... if you could finish it... you could rest... sleep..." (CG 89). Voice oscillates between storytelling and the need to find a story, which is the last story. He is willing to finish his life and being in the world. Voice is looking to hide its own identity by knowing that all of these are going toward death because he is aware of the temporality and spatiality of his life. Cascando contains a fear of ending. It begins with the time for creation, which should come with a place of creation as well. It talks about aliveness passes and he is waiting for something, which has been postponed, all through his being in the world (death). In Cascando Voice, "speaks of 'him' as 'a ton weight' who is 'stuck in the sand"" (Butler 121). The play begins with:

[cold] It is the month of May... for me. [Pause.] Correct. [Pause.] I open.

story... if you could finish it... you could rest... sleep... not before... oh I know... the ones I've finished... thousands and one... all I ever did... in my life... with my life... saying to myself... finish this one... it's the right one... then rest... sleep... no more stories... no more words... and finished it... and not the right one... couldn't rest... straight away another... to begin... to finish... saying to myself... finish this one... then rest... this time... it's the right one... this time... you have it... and finished $i$ it... and not the right one... couldn't rest... straight away another.. but this one... it's different... I'll finish it..." (CG 89)

He wants to finish the life; finishes something that he does not sure about the exact time of its finishing. He is somehow in fear, which is with human all through his being in the world. Existing of choice in the life of human being, he is not an object so he has choices, even he could put an end to his being via suicide. "He has the choice" (CG 89). The word 'Cascando' is a Spanish which means crack open, "in effect,
Opener cracks open, pouring out his thoughts" (Weiss 88). Voice has the desire of continuing his life with the fear and awareness of the existence of death. He empties his mind and talks about his willingness to finish the story, the last story which is his own life. "The story is his life" (Kenner 173). He wants his life to end because he knows that it is going to finish anyway in an unknown time, so he is afraid and wants this to end. There is a deal in some of Beckett's plays that the whole story shows Being-toward-death. "In Being and Time Heidegger engages the temporality and finitude of the question of being as encountered through Dasein's futurity (being-toward-death) and historicity" (Vallega 8). The voice wants to finish everything and there will be no words, there will be nothing, no spatiality for him after death:

give up . . . then rest . . sleep . . not before . . finish .. ... this time ... it's the right one . . . you have it . . you've got ..... . it ... it's there ... somewhere ... you've got him ... follow .................................................... him . . . don't lose him ... Woburn story ... getting on . . ............. . finish . . . then sleep ... no more stories ... no more words

(CG 89)

$\mathrm{He}$ is waiting for his death. As a human being who is aware of his spatiality and temporality of his life, he is waiting for his death to put an end to everything; until then, he has to live, "I have lived on it . . till I'm old. Old enough" (CG 91). He is there nearly close to his death and finishing the story of his life: "Finish . . . no more stories . . . sleep . . . we're there ... nearly

.. " $(C G 94)$. His life is a journey in the world where he has spatiality, but he knows that it is temporal and is going to be finished someday. "The journey to find the source of life and renewal is a descent through darkness and trash where words and meaning do not exist" (Weiss 94-5).

\section{CONCLUSION}

The present article was an investigation of Heidegger's philosophy of being and the concepts of space, time and place in Samuel Beckett's Collected Shorter Plays. Beckett's characters fly over the elements of time that is not what human beings agree and arrange, nor is it something can be measured by clock. Beckett questions the concept of conventional time and shows that clock, and other tools of measurements help people put a duration from the time of birth to death. It concluded that the characters though isolated, are beings who are always already in the world.

It also was concluded that the consequences of the characters' consistent anxiety toward death in their lives comes from projecting their lives onto the horizon of their death, what Heidegger call "being-towards-death" that characterizes authentic human being. The common theme of death in Beckett's plays embodies Heidegger's view on the question of non-existence that has no philosophical relevance. Throughout the plays, it shows that the self can only become what it truly is through confrontation with death.

One of the very early concepts studied in this article was the concept of Dasein that refers to the existence of man and its 
philosophical shadow can be traced in Beckett's work. There are many plays like, Act Without Words 1 and Krapp's Last Tape which focus on human beings rather than their surroundings. Such a view creates static impression, which can influence the physical mobility in Beckett's plays. This article showed the characters' beings in Beckett's plays and their transformation through space, time, and place that sometimes lead to a change in their identities. It is proved that Beckett's style of writing has the signs of Heideggerian concepts of space, time, and place and Bakhtin's architectonic, which is connected to the human being change through time. Bakhtinian unity of time and space was found in Beckett's plays. His plays also discuss the place, where these phenomena find their meaning.

Further, it was found that the characters always involve with their past and future that is what Heidegger calls ways to be. This characteristic in the plays portrayed human as to exist with a certain past, a personal and cultural history and by an open series of possibilities. Beckett's specific setting and physical design for plays entail that the world itself is a part of the fundamental constitution of what it means to be human and that the characters' being and that of the world are not distinguished for the most part.

The article used some plays of Samuel Beckett, Play, Embers, Eh Joe, Ohio Impromptu, That Time, and Rockaby. It utilized them in order to describe Heidegger's concept of time. This work showed that time is not eternal but temporal which ends with a being death. Time and Being are bound together reciprocal as we saw in Beckett's plays. Therefore, before death and becoming undone human beings must fulfill their aims in the world. In order to feel alive they need someone to hear them and being all alone in the world is a kind of death and losing authenticity.

\section{REFERENCES}

Alweiss, L. (2002). "Heidegger and the Concept of Time." History of the Human Sciences 15.3. 117-123.

Bakhtin, M M. (1993). Toward a Philosophy of the Act. Trans. Vadim Liapunov. Txas: U of Texas P.
Bardon, A. (2013). A Brief History of the Philosophy of Time. New York: Oxford UP,

Beckett, S. (2010). The Collected Short Plays. New York: Grove,

Butler, L. St. J. (1979). “A Reading of Samuel Beckett in the Light of Hegel, Heidegger and Sartre." Stirling U, Diss.

Cohn, Ruby. (2005). A Beckett Canon. Michigan: Michigan UP.

Heidegger, M. (2008). Being and Time. New York: Harper Perennial Modern Classics.

(1992a). History of the Concept of Time. Indiana: Indiana University Press.

(1992b). The Concept of Time. Trans. William McNeill. Oxford: Basil Blackwell.

(1991). Nietzsche: Volume II: The Eternal Recurrence of the Same. Trans. David Farrell Krell. San Francisco: Harper.

(1993). Basic Writings. Amsterdam: HarperCollins,

Kennedy, A. (1989). Samuel Beckett. Cambridge: Cambridge UP.

Kenner, H. (1996). A Reader's Guide to Samuel Beckett. Syracuse: Syracuse UP.

Moran, D. (2014). "Beckett and Philosophy." U College Dublin. 193-110.

Ruch, Alexander. (2009). "Fictions of the Afterlife: Temporality and Belief in Late Modernism." Durham: Duke U, Diss.

Shalghin, A. (2014). "Time, Waiting, and Entrapment in Samuel Beckett.” Jadara U 4.9(1). 101-117.

Vallega, p. (2003). Alejandro A. Heidegger and the Issue of Space. Pennsylvania: The Pennsylvania State UP,

Weiss, K. (2013). The Plays of Samuel Beckett. New York: Bloomsbury,

Wynands, S. (2007). Iconic Spaces: The Dark Theology of Samuel Beckett's Drama. Notre Dame: U of Notre Dame. 